\title{
Keefektifan Metode Eksperimen Terhadap Keterampilan Proses dan Hasil Belajar IPA Siswa Kelas VIII SMP
}

\author{
Anik Purwanti ${ }^{1} *$ \\ ${ }^{1}$ SMPN 2 Pangkalpinang. Pangkalpinang, Kep. Bangka Belitung, Indonesia. \\ * Korespondensi Penulis. E-mail: anikuny22@yahoo.co.id \\ Received:10 January 2017; Revised:10 March 2017; Accepted: 10 April 2017
}

\begin{abstract}
Abstrak
Penelitian ini bertujuan untuk mendeskripsikan dan mengetahui perbedaan keefektifan pembelajaran IPA menggunakan metode eksperimen dan demonstrasi ditinjau dari keterampilan proses dan hasil belajar IPA. Penelitian ini merupakan penelitian eksperimen semu. Populasi penelitian adalah siswa kelas VIII SMP Diponegoro Depok Sleman pada tahun ajaran 2013/2014 dan dipilih secara acak sebanyak dua kelas sebagai sampel penelitian. Pengumpulan data dilakukan dengan pretest dan posttest untuk hasil belajar sedangkan untuk keterampilan proses diambil dari data kemampuan awal dan kemampuan akhir yang merupakan hasil observasi pada LKS. Untuk mengetahui efektif tidaknya metode eksperimen dilakukan uji one sample t-test. Kemudian untuk mengetahui perbedaan keefektifan metode eksperimen dan demonstrasi dilakukan uji multivariat dengan uji $T^{2}$ Hotelling dan dilanjutkan analisis univariat dengan uji independent sample t test. Hasil penelitian menunjukkan bahwa (1) pembelajaran IPA menggunakan metode eksperimen efektif ditinjau dari keterampilan proses dan hasil belajar IPA, dan (2) pembelajaran IPA menggunakan metode eksperimen lebih efektif dalam meningkatkan keterampilan proses dan hasil belajar IPA dibandingkan dengan metode demonstrasi.
\end{abstract}

Kata Kunci: Keefektifan, metode eksperimen, keterampilan proses, hasil belajar IPA.

\section{The Effectiveness of Experiment Method on Process Skills and The Science Learning Achievement of Grade VIII students in SMP}

\begin{abstract}
This study aimed to describe and to know difference of the effectiveness of science teachinglearning using experiment and demonstration method on the process skills and science learning achievement. This research was a quasi experiment research. The population of the research was all of students of SMP Diponegoro Depok Sleman grade VIII in the academic year of 2013/2014 and selected randomly two classes as sample of research. A pretest and posttest were used to collect the data of the learning achievement, while the process skill was taken from the prior ability and the final ability which were the result of observation on the LKS (Students Worksheet). To obtain the effectiveness of the experiment method on each variable, the data were analyzed with one sample ttest. Then, to find the difference between the effectiveness of the experiment and demonstration method on all variables used multivariate technique with $T^{2}$ Hotelling and followed by univariate analysis with independent sample $t$ test. The results of the research showed that (1) the teaching-learning process of science using the experiment method was effective in terms of process skills and science learning achievement of the students, and (2) the teaching-learning process of science using experiment method was more effective in improving the process skills and science learning achievement than that using the demonstration method.
\end{abstract}

Keywords: Effectiveness, experiment method, science process skills, science learning achievement

How to Cite: Purwanti, A. (2017). Keefektifan metode eksperimen terhadap keterampilan proses dan hasil belajar IPA siswa kelas VIII SMP. Jurnal Pendidikan Matematika dan Sains, 5(1). doi:http://dx.doi.org/10.21831/jpms.v5i1.13458

Permalink/DOI: DOI: http://dx.doi.org/10.21831/jpms.v5i1.13458 


\section{PENDAHULUAN}

IPA merupakan bidang kajian terhadap alam semesta dan segala proses yang terjadi di dalamnya sebagai objek. IPA dipelajari dengan cara menginvestigasi. Metode investigasi meliputi keinginan untuk memahami alam melalui eksperimen, observasi, hipotesis, validitas sebagai pengetahuan dari disiplin ilmu yang representatif seperti fakta, konsep, prinsip, hukum, teori dan model-model khusus untuk materi IPA (Chiappetta \& Collette, 1994, p. 33). Dengan demikian tujuan mata pelajaran IPA di sekolah juga harus mengacu pada proses investigasi tersebut.

Tujuan dari mata pelajaran IPA di SMP/ MTs di antaranya (1) melakukan inkuiri ilmiah untuk menumbuhkan kemampuan berpikir, bersikap dan bertindak ilmiah serta berkomunikasi; dan (2) meningkatkan pengetahuan, konsep, dan keterampilan IPA sebagai dasar untuk melanjutkan pendidikan ke jenjang selanjutnya (Depdiknas, 2006a, p.377). Salah satu Standar Kompetensi Lulusan (SKL) pada mata pelajaran IPA untuk SMP/MTs adalah melakukan pengamatan dengan peralatan yang sesuai, melaksanakan percobaan sesuai prosedur, mencatat hasil pengamatan, pengukuran dalam tabel dan grafik yang sesuai, membuat kesimpulan, mengkomunikasikan secara lisan dan tertulis sesuai dengan bukti yang diperoleh, maka dari itu pembelajaran di sekolah menekankan penggunaan metode pembelajaran IPA yang mencakup kinerja ilmiah (Depdiknas, 2006b, p.24).

Berdasarkan pada tujuan mata pelajaran IPA dan SKL, maka proses dalam pembelajaraan IPA berkaitan dengan usaha untuk meningkatkan keterampilan proses. Suatu keterampilan akan dikuasai apabila siswa itu melakukan praktik atau latihan secara berulangulang. IPA berkaitan dengan cara mencari tahu tentang alam secara sistematis, sehingga IPA bukan hanya pengua-saan pengetahuan, fakta, konsep atau prinsip saja tetapi juga merupakan suatu proses penemuan. Oleh karena itu, proses pembelajaran IPA mene-kankan pada pemberian pengalaman secara lang-sung untuk meningkatkan keterampilan proses IPA, sehingga dapat membantu siswa untuk memperoleh pemahaman yang lebih mendalam. Kenyataan saat ini masih banyak siswa yang hanya mempelajari IPA sebagai produk.

Pembelajaran IPA merupakan kegiatan komplek yang semestinya dilakukan untuk mem-peroleh pengetahuan IPA sekaligus keterampilan IPA dan sikap ilmiah (Subamia, 2012, p.28). Keberhasilan dalam proses belajar mengajar demi tercapainya tujuan pembelajaran perlu menggunakan metode pembelajaran yang tepat (Nopitasari, Indrowati \& Santosa, 2012, p.102). Demonstrasi dan eksperimen merupakan metode interaksi edukatif yang sangat efektif dalam menolong siswa mencari jawaban atas per-tanyaan misalnya "bagaimana prosesnya"? (Zuldafrial, 2012, p.60). Metode ini kebanyakan digunakan dalam bidang ilmu pengetahuan alam.

Berdasarkan hasil wawancara dengan guru IPA di SMP Diponegoro Depok, Magowoharjo Depok Sleman Yogyakarta menunjukkan bahwa pembelajaran IPA menggunakan berbagai meto-de dengan menyesuaikan materi yang diajarkan. Metode yang digunakan di antaranya metode ceramah, metode tanya jawab, metode pemberian tugas, metode konvensional dan metode demon-strasi daripada menggunakan metode ekspe-rimen. Namun yang sering digunakan dalam pembelajaran IPA di SMP Diponegoro Depok, Magowoharjo Depok Sleman Yogyakarta adalah dengan menggunakan metode demonstrasi.

Pendidikan di sekolah berkaitan erat dengan kualitas pembelajaran yang dilakukan oleh guru dan siswa di tingkat kelas. Kualitas pembelajaran ditinjau dari segi proses, dikatakan berhasil dan berkualitas apabila seluruhnya atau setidak-tidaknya sebagian besar siswa terlibat secara aktif, baik fisik, mental, maupun sosial dalam proses pembelajaran, menunjukkan semangat belajar yang tinggi dan rasa percaya pada diri sendiri (Listyaningrum, Sujidan \& Suciati, 2012, p.57). Proses pembelajaran IPA harus mempertimbangkan metode dan strategi pembelajaran yang efektif dan efisien. Dalam hal ini metode eksperimen dan demonstrasi keduanya sama-sama melibatkan siswa secara aktif dalam pembelajaran melalui kegiatan observasi atau pengamatan. Ciri dari pembelajaran IPA adalah melibatkan siswa dalam kegiatan praktik di sekolah (Abraham \& Millar, 2008, p.1945). Pengajaran yang efektif itu harus mengoptimalkan pembelajaran siswa secara efektif dan belajar tentang keterampilan (Ango, 2002, p.27).

Metode eksperimen adalah cara penyajian pelajaran, di mana siswa melakukan eksperimen dengan mengalami, menemukan sendiri sesuatu yang dipelajari, mengikuti suatu proses, mengamati suatu objek, menganalisis, membuktikan dan menarik kesimpulan sendiri mengenai suatu objek, keadaan atau proses sesuatu (Djamarah \& 
Zain, 1996, p.95). Keunggulan dari metode eksperimen yang digunakan dalam pembelajaran di antaranya (a) siswa terlatih menggunakan metode ilmiah dalam menghadapi segala masalah; (b) siswa lebih aktif berpikir dan berbuat; (c) siswa menemukan pengalaman praktis dan keterampilan dalam menggunakan alat-alat eksperimen; dan (d) siswa dapat membuktikan sendiri kebenaran suatu teori (Roestiyah, 2008, p.82). Proses penemuan konsep dengan menggunakan keterampilan proses IPA memungkinkan melatih siswa untuk berpikir lebih aktif dan kreatif (Alia \& Supriyono, 2013, p.51). Selain itu metode eksperimen dapat meningkatkan keterampilan proses sains secara signifikan (Subekti \& Ariswan, 2016) dan berpengaruh terhadap pencapaian prestasi belajar siswa (Murwani \& Wibowo, 2013)

Selain metode eksperimen, metode yang sering digunakan oleh guru dalam pembelajaran IPA adalah metode demonstrasi. Metode demon-strasi merupakan metode penyajian pelajaran dengan memperagakan dan mempertunjukkan kepada siswa tentang suatu proses, situasi atau benda tertentu, baik sebenarnya atau hanya sekedar tiruan (Majid, 2013, p.197). Dengan metode demonstrasi siswa mendapat gambaran secara langsung apa yang dipelajari, walaupun tidak semua siswa dapat mencoba di kelas (Purnawirawanti, Sarwanto \& Sugiyarto, 2013, p.78). Metode demonstrasi mempunyai kelebih-an, antara lain (1) perhatian siswa dapat dipusat-kan kepada hal-hal yang dianggap penting oleh guru; (2) dapat membimbing siswa ke arah ber-pikir yang sama; (3) ekonomis dalam jam pela-jaran di sekolah; (4) dapat mengurangi kesalah-an-kesalahan bila dibandingkan dengan hanya membaca dan mendengarkan, dan (5) tidak memerlukan keterangan yang banyak (Sagala, 2003, p.211).

Penggunaan metode pembelajaran yang efektif ini diharapkan dapat membuat siswa tidak sekedar menerima materi dari guru tetapi juga bagaimana cara atau proses mendapatkan konsep/pengetahuan tersebut. Dengan demikian siswa dapat belajar dengan mengembangkan keterampilan proses IPA sehingga dapat memahami konsep-konsep IPA dan meningkatkan daya ingat terhadap konsep-konsep tersebut yang berdampak pada hasil belajar IPA. Oleh karena itu, perlu dilakukan penelitian mengenai keefek-tifan metode eksperimen untuk meningkatkan keterampilan proses dan hasil belajar IPA siswa kelas VIII SMP Diponegoro Depok, Magu-woharjo Depok Sleman
Yogyakarta dengan pokok bahasan cahaya. Di samping itu diteliti juga keefektifan metode demonstrasi sebagai pengontrolnya.

Berdasarkan permasalahan yang telah dikemukakan berikut kajian teorinya, maka tujuan penelitian ini adalah untuk (1) mengetahui keefektifan pembelajaran IPA menggunakan metode eksperimen ditinjau dari keterampilan proses dan hasil belajar IPA, dan (2) mengetahui perbedaan keefektifan antara pembelajaran IPA menggunakan metode eksperimen dan demon-strasi ditinjau dari keterampilan proses dan hasil belajar IPA siswa kelas VIII SMP Diponegoro Depok, Magowoharjo Depok Sleman Yogyakarta.

\section{METODE}

Penelitian ini menggunakan pendekatan kuantitatif dengan jenis penelitian eksperimen semu. Penelitian ini menggunakan dua kelompok yaitu kelompok eksperimen dan kelompok kontrol. Desain penelitiannya adalah pretest posttest control group design. Populasi penelitian ini adalah siswa-siswi kelas VIII SMP Dipo-negoro Depok Maguwoharjo Sleman Yogyakarta tahun pelajaran 2013/2014 yang berjumlah 4 kelas paralel dengan jumlah siswa 128 orang. Sampel ditetapkan dengan teknik simple random sampling, memilih secara acak dua kelas dari empat kelas yang ada. Kelas VIII A sebanyak 32 siswa merupakan kelompok eksperimen yang proses pembelajarannya menggunakan metode eksperimen, dan kelas VIII B sebanyak 33 siswa merupakan kelompok kontrol yang proses pembelajarannya menggunakan metode demon-strasi.

Variabel bebas terdiri dari metode eksperimen dan metode demonstrasi. Variabel terikat yaitu keterampilan proses IPA dan hasil belajar IPA. Teknik pengumpulan data dalam penelitian ini dengan menggunakan teknik nontes untuk keterampilan proses IPA dengan menggu-nakan instrumen lembar observasi yang didu-kung dengan pertanyaan yang ada pada LKS dan teknik tes untuk hasil belajar IPA yang meng-gunakan instrumen berupa tes tertulis pilihan ganda. Instrumen tes hasil belajar IPA dilak-sanakan sebanyak dua kali yaitu pretest dan posttest.

Validitas instrumen dalam penelitian ini adalah validitas isi, konstruk dan empiris. Instrumen yang di validasi di antaranya perangkat pembelajaran seperti silabus, RPP, LKS dan instrumen soal tes hasil belajar IPA dan lembar observasi keterampilan proses IPA. Semua 
instrumen tersebut divalidasi isi dan konstruk oleh dua dosen ahli selaku expert judgement. Instrumen tes hasil belajar selanjutnya divalidasi secara empiris. Hal ini dilakukan dengan cara tes uji coba instrumen hasil belajar IPA pada siswa kelas IX di SMP Diponegoro Depok yang sudah pernah mendapatkan materi tentang cahaya dengan jumlah responden sebanyak 47 siswa.

Uji asumsi analisis data dilakukan dengan uji normalitas dan uji homogenitas. Data yang digunakan untuk uji normalitas dan uji homogenitas adalah data kemampuan awal, kemampuan akhir keterampilan proses IPA dan pretest, posttest hasil belajar IPA. Uji normalitas menggunakan teknik statistik Kolmogorov-Smirnov. Pengambilan keputusan untuk uji normalitas jika nilai signifikansi $>0,05$ maka data berdistribusi normal (Priyatno, 2012, p.90).

Uji homogenitas dilakukan terhadap masing-masing variabel dependen (univariat) dan terhadap keseluruhan variabel dependen (multivariat). Uji homogenitas multivariat secara bersama-sama menggunakan Uji Box's $M$. Uji homogenitas varian dilakukan terhadap masingmasing variabel dependen (univariat) menggunakan uji Levene's. Metode pengambilan keputusan untuk uji Box's $M$ dan uji Levene's (nilai F) adalah jika nilai signifikan > 0,05 maka varian-kovarian sama atau homogen. (Priyatno, 2012, p.79).

Untuk mengetahui keefektifan dari masing-masing metode pembelajaran terhadap keterampilan proses IPA maupun hasil belajar IPA dilakukan uji one sample $t$ test. Untuk menyelidiki ada tidaknya perbedaan keefektifan atas penerapan metode eksperimen dan metode demonstrasi ditinjau dari keterampilan proses dan hasil belajar IPA siswa dilakukan dengan uji multivariat. Teknik statistik yang digunakan multivariate tests terhadap pretest dan posttest. Uji analisis varian multivariat pada pretest bertujuan untuk mengetahui kesamaan rata-rata (mean) skor perolehan sebelum diberi perlakuan yang menunjukkan bahwa kemampuan kedua kelompok tersebut adalah sama. Uji Multivariat pada posttest bertujuan untuk melihat perbedaan rata-rata (mean), yang menunjukkan adanya perbedaan dari hasil perlakuan yang telah diberikan.Uji multivariat dengan menggunakan $T^{2}$ Hotelling, dianalisis dengan bantuan SPSS.

Uji univariat yang digunakan adalah uji independen sample t test. Uji univariat atau uji lanjut bertujuan untuk mengetahui metode pembelajaran yang lebih efektif antara kedua metode yaitu metode eksperimen dan demonstrasi baik ditinjau dari keterampilan proses maupun hasil belajar IPA.

\section{HASIL DAN PEMBAHASAN}

\section{Hasil Uji Normalitas}

Uji normalitas dilakukan untuk mengetahui apakah populasi berdistribusi normal atau tidak. Hasil uji normalitas untuk variabel keterampilan proses IPA dapat dilihat pada Tabel 1.

Tabel 1. Hasil Uji Normalitas KolmogorovSmirnov Pretest dan Postest

\begin{tabular}{clccc}
\hline & \multirow{2}{*}{ Kelompok } & \multicolumn{3}{c}{ Kolmogorov-Smirnov } \\
\cline { 3 - 5 } & & Df & Sig. & Ket \\
\hline Pretest & Eksperimen & 32 & 0,159 & Normal \\
KP & Kontrol & 33 & 0,065 & Normal \\
Pretest & Eksperimen & 32 & 0,093 & Normal \\
HB & Kontrol & 33 & 0,195 & Normal \\
Posttest & Eksperimen & 32 & 0,200 & Normal \\
KP & Kontrol & 33 & 0,066 & Normal \\
Posttest & Eksperimen & 32 & 0,200 & Normal \\
HB & Kontrol & 33 & 0,076 & Normal \\
\hline
\end{tabular}

Keterangan : $\quad \mathrm{KP}=$ Keterampilan Proses

$\mathrm{HB}=$ Hasil Belajar

Berdasarkan Tabel 6 terlihat bahwa nilai signifikansi dari keseluruhan data baik kelompok eksperimen dan kelompok kontrol lebih besar dari 0,05. Dengan demikian data tersebut berdistribusi normal.

\section{Hasil Uji Homogenitas}

Uji homogenitas terhadap keterampilan proses dan hasil belajar IPA secara bersamasama menggunakan uji Box's $M$. Hasil perhitungan uji homogenitas multivariat dengan bantuan SPSS disajikan dalam Tabel 2.

Tabel 2. Hasil Uji Homogenitas Multivariat

\begin{tabular}{ccccc}
\hline Aspek & Box's $\boldsymbol{M}$ & F & Sig & Ket \\
\hline Pretest & 1,277 & 0.411 & 0,745 & Homogen \\
Posttest & 3,217 & 1,036 & 0,375 & Homogen \\
\hline
\end{tabular}

Berdasarkan Tabel 2 dapat dilihat bahwa nilai signifikansi yang diperoleh adalah 0,745 (Pretest) dan 0,375 (Posttest). Karena nilai signifikansi >0,05 maka dapat disimpulkan bahwa kedua populasi memiliki kovarian yang homogen.

Hasil perhitungan uji homogenitas univariat dengan bantuan SPSS disajikan pada Tabel 3. Berdasarkan Tabel 3 terlihat bahwa nilai signifikansi untuk keterampilan proses dan hasil belajar IPA baik sebelum maupun sesudah per- 
lakuan lebih besar dari 0,05 maka kedua populasi memiliki varian yang sama homogen.

Tabel 3. Hasil Uji Homogenitas Univariat Data Pretest dan Posttest

\begin{tabular}{cccc}
\hline Aspek & F & Sig & Keterangan \\
\hline Pretest $K P$ & 0,555 & 0,459 & Homogen \\
Pretest $H B$ & 0,999 & 0,321 & Homogen \\
Posttest $K P$ & 2,337 & 0,131 & Homogen \\
Posttest $H B$ & 0,008 & 0,927 & Homogen \\
\hline
\end{tabular}

Keterangan : KP $=$ Keterampilan Proses $\mathrm{HB}=$ Hasil Belajar

\section{Hasil Observasi Keterampilan Proses IPA}

Hasil observasi keterampilan proses IPA terdiri atas data hasil observasi pada LKS ke-1 sebagai data kemampuan awal (pretest) dan data rata-rata hasil observasi pada LKS ke-2 sampai LKS ke-11 sebagai data kemampuan akhir (posttest). Ringkasan deskripsi mengenai data keterampilan proses IPA dapat dilihat pada Tabel 4.

Tabel 4. Deskripsi Data Keterampilan Proses

\begin{tabular}{ccccc}
\hline \multirow{2}{*}{ Deskripsi } & \multicolumn{2}{c}{$\begin{array}{c}\text { Metode } \\
\text { Eksperimen }\end{array}$} & \multicolumn{2}{c}{$\begin{array}{c}\text { Metode } \\
\text { Demonstrasi }\end{array}$} \\
\cline { 2 - 5 } & Kemampuan & \multicolumn{2}{c}{ Kemampuan } \\
\cline { 2 - 5 } & Awal & Akhir & Awal & Akhir \\
\hline Rata-rata & 51,56 & 80,88 & 50,15 & 72,85 \\
St. Dev & 9,370 & 6,079 & 10,192 & 7,146 \\
Skor & 70 & 93 & 70 & 88 \\
maksimal & 30 & 64 & 30 & 62 \\
Skor minimal & 30 & 32 & 33 & 33 \\
Jumlah siswa & 32 & 32 & 15,6 & 90,9 \\
\% ketuntasan & 15,6 & 96,9 & \multicolumn{2}{c}{$\mathbf{7 5 , 3}$} \\
Peningkatan & \multicolumn{2}{c}{$\mathbf{8 1 , 3}$} & \multicolumn{2}{c}{} \\
Ketuntasan \% & \multicolumn{3}{c}{} \\
\hline
\end{tabular}

Berdasarkan Tabel 4 persentase ketuntasan kemampuan awal untuk pembelajaran dengan metode eksperimen dan demonstrasi sebesar 15,6\%. Dengan adanya perlakuan diperoleh persentase ketuntasan kemampuan akhir yang menggunakan metode eksperimen diperoleh persentase sebesar 96,9\% yang mencapai ketuntasan minimal, sedangkan pada metode demonstrasi sebesar 90,9\%. Hal ini menunjukkan bahwa lebih dari $75 \%$ siswa yang mencapai KKM maka pembelajaran IPA untuk metode eksperimen dan demonstrasi efektif ditinjau dari keterampilan proses.

Kriteria penilaian aspek keterampilan proses IPA yang diukur sebanyak 5 aspek pada penguasaan keterampilan proses IPA oleh observer yang didukung dengan pertanyaan pada
LKS. Skala penilaian yang digunakan yaitu 4, 3, 2 dan 1 sesuai dengan lembar observasi keterampilan proses.

Distribusi frekuensi dan persentase keterampilan proses IPA sebelum dan setelah perlakuan berdasarkan kriteria keterampilan proses IPA disajikan pada Tabel 5.

Tabel 5. Distribusi Frekuensi Perolehan Skor Keterampilan Proses IPA

\begin{tabular}{cccccccccc}
\hline \multirow{2}{*}{$\begin{array}{c}\text { Krite- } \\
\text { ria }\end{array}$} & \multicolumn{3}{c}{ Metode Eksperimen } & \multicolumn{3}{c}{ Metode Demonstrasi } \\
\cline { 2 - 9 } & \multicolumn{2}{c}{ Awal } & \multicolumn{2}{c}{ Akhir } & \multicolumn{3}{c}{ Awal } & \multicolumn{3}{c}{ Akhir } \\
\cline { 2 - 9 } & $\mathrm{F}$ & $\%$ & $\mathrm{f}$ & $\%$ & $\mathrm{f}$ & $\%$ & $\mathrm{f}$ & $\%$ \\
\hline Sangat & 0 & 0 & 16 & 50 & 0 & 0 & 10 & 30,3 \\
Tinggi & & & & & & & & \\
Tinggi & 1 & 3,1 & 15 & 46,9 & 1 & 3,0 & 19 & 57,6 \\
Sedang & 8 & 25 & 1 & 3,1 & 7 & 21,2 & 4 & 12,1 \\
Rendah & 1 & 56,3 & 0 & 0 & 15 & 45,5 & 0 & 0 \\
Sangat & 8 & 5 & 15,6 & 0 & 0 & 10 & 30,3 & 0 & 0 \\
Rendah & 3 & 100 & 3 & 100 & 33 & 100 & 33 & 100 \\
Jumlah & 2 & 100 & 2 & & & & & & \\
\hline
\end{tabular}

Keterangan $\mathrm{f}=$ frekuensi

Berdasarkan Tabel 5 menunjukkan bahwa untuk kemampuan awal baik pada kelompok eksperimen maupun kelompok kontrol memiliki skor rata-rata keterampilam proses IPA pada kategori rendah. Jika dilihat pada kemampuan akhirnya untuk kelompok eksperimen dan kontrol memiliki skor rata-rata keterampilan proses IPA pada kategori tinggi.

\section{Hasil Tes untuk Hasil Belajar IPA}

Hasil belajar IPA yang dideskripsikan berupa skor data pretest dan posttest hasil belajar IPA. Ringkasan deskriptif mengenai data tes hasil belajar IPA dapat dilihat pada Tabel 6 .

Tabel 6. Deskripsi Data Hasil Belajar

\begin{tabular}{ccccc}
\hline \multirow{2}{*}{ Deskripsi } & \multicolumn{2}{c}{ Met.Eksperimen } & \multicolumn{2}{c}{ Met.Demonstrasi } \\
\cline { 2 - 5 } & Pretest & Posttest & Pretest & Posttest \\
\hline Rata-rata & 39,34 & 80,44 & 39,91 & 75,21 \\
St. Dev & 14,296 & 8,747 & 16,214 & 8,905 \\
Skor maksimal & 60 & 93 & 63 & 90 \\
Skor minimal & 7 & 63 & 7 & 60 \\
Jumlah siswa & 32 & 32 & 33 & 33 \\
\% ketuntasan & 0 & 96,9 & 0 & 84,8 \\
Peningkatan & \multicolumn{2}{c}{$\mathbf{9 6 , 9}$} & \multicolumn{2}{c}{$\mathbf{8 4 , 8}$} \\
Ketuntasan \% & \multicolumn{2}{c}{} \\
\hline
\end{tabular}

Berdasarkan Tabel 6 persentase ketuntasan untuk pretest sebesar $0 \%$ siswa yang mencapai ketuntasan minimal 65. Persentase ketuntasan untuk posttest pada kelompok eksperimen sebesar 96,9\% siswa yang mencapai ketuntasan 
mini-mal, sedangkan pada kelompok kontrol sebesar $84,8 \%$. Berdasarkan presentase ketuntasan dari kedua metode telah mencapai 75\% siswa yang mencapai ketuntasan. Hal ini menunjukkan bah-wa pembelajaran IPA dengan kedua metode tersebut efektif ditinjau dari hasil belajar IPA.

Distribusi frekuensi dan persentase hasil belajar sebelum dan setelah perlakuan berdasarkan kriteria hasil belajar IPA disajikan pada Tabel 7.

Tabel 7. Distribusi Frekuensi Perolehan Skor Hasil Belajar IPA

\begin{tabular}{cccccccccc}
\hline & \multicolumn{3}{c}{ Metode Eksperimen Tetode Demonstrasi } \\
\cline { 2 - 9 } Krite & \multicolumn{3}{c}{ Kemampuan } & \multicolumn{3}{c}{ Kemampuan } \\
\cline { 2 - 9 } ria & \multicolumn{2}{c}{ Awal } & \multicolumn{2}{c}{ Akhir } & \multicolumn{2}{c}{ Awal } & \multicolumn{2}{c}{ Akhir } \\
\cline { 2 - 9 } & $\mathbf{f}$ & $\%$ & f & $\%$ & f & $\%$ & f & $\%$ \\
\hline Sangat & 0 & 0 & 16 & 50 & 0 & 0 & 10 & 30,3 \\
Tinggi & & & & & & & \\
Tinggi & 1 & 3,1 & 15 & 46,9 & 1 & 3,0 & 19 & 57,6 \\
Sedang & 8 & 25 & 1 & 3,1 & 7 & 21,2 & 4 & 12,1 \\
Rendah & 18 & 56,3 & 0 & 0 & 15 & 45,5 & 0 & 0 \\
Sangat & 5 & 15,6 & 0 & 0 & 10 & 30,3 & 0 & 0 \\
Rendah & & 100 & 32 & 100 & 33 & 100 & 33 & 100 \\
Jumlah & 32 & 100 &
\end{tabular}

Keterangan $\mathrm{f}=$ frekuensi

Berdasarkan Tabel 7 menunjukkan bahwa skor pretest hasil belajar IPA pada kedua kelompok memiliki hasil belajar IPA rata-rata pada kategori rendah. Namun jika dilihat pada skor posttest untuk kelompok eksperimen sebagian besar siswa setelah mendapatkan pembelajaran dengan metode eksperimen memiliki hasil belajar IPA sangat tinggi, sedangkan pada kelompok kontrol memperoleh skor posttest untuk hasil belajar termasuk dalam kategori tinggi.

\section{Hasil Uji Hipotesis}

\section{Uji one sample t-test}

Uji one sample t-test dilakukan untuk melihat keefektifan dari masing-masing metode pembelajaran baik terhadap keterampilan proses IPA maupun hasil belajar IPA. Kriteria keputusan untuk uji one sample $t$ test berdasarkan nilai signifikansi adalah jika nilai signifikansi $<0,05$ maka $\mathrm{H}_{\mathrm{o}}$ ditolak. Hasil uji one sample t-test untuk kedua kelompok dapat dilihat pada Tabel 8.

Tabel 8. Hasil Uji One Sample t-Test

\begin{tabular}{cccccc}
\hline Metode & Variabel & $\bar{x}$ & df & t & Sig \\
\hline \multirow{2}{*}{ Eksperimen } & KP & 80,875 & 31 & 75,261 & 0,000 \\
& $\mathrm{HB}$ & 80,438 & 31 & 52,020 & 0,000 \\
\multirow{3}{*}{ Demonstrasi } & $\mathrm{KP}$ & 75,848 & 32 & 60,971 & 0,000 \\
& $\mathrm{HB}$ & 75,212 & 32 & 48,519 & 0,000 \\
\hline
\end{tabular}

Keterangan: $\mathrm{KP}=$ Keterampilan Proses

$$
\mathrm{HB}=\text { Hasil Belajar }
$$

Bedasarkan Tabel 8 pada kelompok eksperimen yang proses pembelajarannya menggunakan metode eksperimen untuk variabel keterampilan proses dan hasil belajar IPA diperoleh nilai signifikansi yaitu 0,000 dan 0,000 . Karena nilai signifikansi $\leq 0,05$ maka $\mathrm{H}_{\mathrm{o}}$ ditolak. Hal ini menunjukkan bahwa pada pembelajaran IPA menggunakan metode eksperimen efektif baik ditinjau dari keterampilan proses IPA maupun hasil belajar IPA.

\section{Hasil Uji Multivariat}

Uji multivariat digunakan untuk mengetahui ada atau tidaknya perbedaan keefektifan kedua metode pembelajaran tersebut. Uji multivariat dilakukan pada pretest dan posttest. Metode pengambilan keputusan untuk uji multivariate dengan melihat Hotelling Trace adalah jika nilai signifikan >0,05 maka $\mathrm{H}_{\mathrm{o}}$ diterima (Priyatno, 2012, p.82). Hasil uji $T^{2}$ Hotelling data pretest dapat dilihat pada Tabel 9.

Tabel 9. Hasil Uji $T^{2}$ Hotelling Pretest

\begin{tabular}{ccccc}
\hline Effek & F & $\begin{array}{c}\text { Hypothesis } \\
\text { Df }\end{array}$ & Sig & Ket \\
\hline $\begin{array}{c}\text { Hotelling's } \\
\text { Trace }\end{array}$ & 0,182 & 2,000 & 0,834 & $\mathrm{H}_{\mathrm{o}}$ diterima \\
\hline
\end{tabular}

Berdasarkan Tabel 9 menunjukkan tingkat keefektifan sebelum dilakukan pembelajaran, nilai signifikansi adalah 0,834 . Karena nilai signifikan > 0,05 $(0,843>0,05)$ berarti bahwa $\mathrm{H}_{\mathrm{o}}$ diterima. Dengan demikian pembelajaran IPA sebelum menggunakan metode eksperimen tidak lebih efektif dalam meningkatkan keterampilan proses dan hasil belajar IPA dibandingkan dengan pembelajaran IPA menggunakan metode demonstrasi. Hal ini disebabkan skor yang dilihat adalah ketika kedua kelompok belum menda-patkan pembelajaran.

Pengujian hipotesis untuk posttest dilakukan pada data skor yang diperoleh dari skor kemampuan akhir keterampilan proses IPA dan postets hasil belajar IPA. Hasil uji $T^{2}$ Hotelling data posttest selengkapnya dapat dilihat pada Tabel 10.

Tabel 10. Hasil Uji $T^{2}$ Hotelling Posttest

\begin{tabular}{ccccc}
\hline Effek & F & $\begin{array}{c}\text { Hypothesis } \\
\text { Df }\end{array}$ & $\begin{array}{c}\text { Error } \\
\text { df }\end{array}$ & Sig \\
\hline $\begin{array}{c}\text { Hotelling's } \\
\text { Trace }\end{array}$ & 5,083 & 2,000 & 62,000 & 0,009 \\
\hline
\end{tabular}


Berdasarkan Tabel 10 menunjukkan tingkat keefektifan setelah dilakukan pembelajaran, nilai signifikansi yang diperoleh adalah 0,009. Karena nilai signifikansinya $\leq 0,05$ maka $\mathrm{H}_{\mathrm{o}}$ ditolak. Dengan demikian, dapat disimpulkan bahwa pembelajaran IPA setelah menggunakan metode eksperimen lebih efektif dalam meningkatkan keterampilan proses dan hasil belajar IPA dibandingkan dengan pembelajaran mengguna-kan metode demonstrasi.

\section{Hasil Uji Lanjut Univariat}

Uji univariat atau uji lanjut bertujuan mengetahui metode pembelajaran yang paling efektif antara kedua metode tersebut terhadap peningkatan keterampilan proses IPA dan hasil belajar IPA. Uji univariat dilakukan dengan uji independen sample $t$ test. Kriteria pengambilan keputusan untuk uji univariat (independen sample $t$ test) adalah dilihat dari nilai signifikansi yaitu $\operatorname{Sig}(2-$ tailed), jika nilai $\operatorname{Sig}(2-$ tailed) < 0,025 maka $\mathrm{H}_{\mathrm{o}}$ ditolak (Trihendradi, 2013, p.119). Hasil analisis univariat dengan SPSS dapat dilihat pada Tabel 11.

Tabel 11.Hasil Uji Independent Sample T Test

\begin{tabular}{ccc}
\hline Variabel. & T & Signifikansi Sig(2-tailed) \\
\hline KP & 3,050 & 0,003 \\
HB & 2,386 & 0,020 \\
\hline
\end{tabular}

Keterangan : KP $=$ Keterampilan Proses

$$
\mathrm{HB}=\text { Hasil Belajar }
$$

Berdasarkan Tabel 11 terlihat bahwa untuk keterampilan proses IPA yang diajarkan dengan metode eksperimen dan metode demonstrasi di dapat nilai signifikansi sebesar 0,003. Karena nilai signifikansi (Sig-2tailed) $<0,025$ sehingga dapat disimpulkan $\mathrm{H}_{\mathrm{o}}$ ditolak. Hal ini berarti bahwa pembelajaran IPA menggunakan metode eksperimen lebih efektif dalam meningkatkan keterampilan proses IPA dibandingkan dengan pembelajaran IPA menggunakan metode demon-strasi.

Berdasarkan Tabel 11 terlihat bahwa untuk hasil belajar IPA yang diajarkan dengan meng-gunakan metode eksperimen dan demontrasi di dapat nilai signifikansi sebesar 0,020. Karena nilai signifikansi (Sig-2tailed) < 0,025 sehingga dapat disimpulkan $\mathrm{H}_{02}$ ditolak. Hal ini berarti bahwa pembelajaran IPA menggunakan metode eksperimen lebih efektif dalam meningkatkan hasil belajar IPA dibandingkan dengan pembe-lajaran IPA menggunakan metode demonstrasi.

\section{Pembahasan}

\section{Keterampilan Proses IPA Siswa Selama Pembelajaran}

\section{Keterampilan Proses Siswa Secara Umum}

Berdasarkan deskripsi data kemampuan awal dan kemampuan akhir keterampilan proses IPA baik pada kelompok eksperimen maupun kelompok kontrol meningkat. Peningkatan ini dapat dilihat dari skor rata-rata kemampuan awal dan kemampuan akhir. Pada kelompok ekspe-rimen skor rata-rata kemampuan awal keteram-pilan proses IPA sebesar 51,56 dan skor rata-rata kemampuan akhirnya sebesar 80,88. Pada kelom-pok kontrol skor rata-rata kemampuan awal keterampilan proses IPA sebesar 50,15 dan skor rata-rata kemampuan akhirnya sebesar 72,85.

Peningkatan keterampilan proses IPA dapat juga dilihat dari persentase siswa yang telah mencapai kriteria ketuntasan minimal (KKM) untuk kelompok eksperimen sebesar $81,3 \%$ siswa yang telah mencapai KKM sedangkan pada kelompok kontrol sebesar $75,3 \%$ dengan KKM yang ditetapkan oleh sekolah sebesar 65. Hal ini menunjukkan bahwa pembelajaran IPA baik dengan metode eksperimen maupun metode demonstrasi efektif untuk meningkatkan kete-rampilan proses IPA karena telah melebihi $75 \%$ siswa yang mencapai KKM.

Data tersebut menunjukkan peningkatan persentase ketuntasan belajar kelompok eksperimen lebih tinggi dibandingkan kelompok kontrol. Hasil uji univariat dengan uji independent sample $t$ test diperoleh nilai sebesar 0,003 $(0,003<\alpha=0,025)$ berarti keterampilan proses IPA siswa yang pembelajarannya menggunakan me-tode eksperimen lebih tinggi dari keterampilan proses IPA siswa yang pembelajarannya meng-gunakan metode demonstrasi.

Dengan demikian, pembelajaran IPA yang menggunakan metode eksperimen lebih efektif dan signifikan dalam meningkatkan keterampilan proses IPA siswa dibandingkan pembelajaran IPA dengan metode demonstrasi. Hal ini dise-babkan pada pembelajaran IPA yang menggu-nakan metode eksperimen siswa berinteraksi langsung dalam kelompok kecilnya sehingga proses mengamati dapat langsung dilakukan oleh siswa itu sendiri sehingga siswa dapat lebih memahami pengetahuan yang berkaitan dengan data yang diperoleh dari eksperimen daripada hanya menerima penjelasan guru. Oleh karena itu, metode 
eksperimen membuat siswa kreatif dan mandiri baik secara individu maupun kelom-pok untuk menggunakan serta mengembangkan keterampilan proses IPA yang dimilikinya.

Pada pembelajaran IPA dengan metode demonstrasi, siswa hanya melihat dan mengamati demonstrasi dalam kelompok besar dan tidak melakukan sendiri meskipun ada beberapa siswa yang terlibat dalam demonstrasi. Hal ini mem-buat siswa yang mengikuti pembelajaran dengan metode demonstrasi tidak mendapatkan konsep/ pengetahuan selengkap yang diamati oleh siswa yang mengikuti pembelajaran menggunakan me-tode eksperimen.

Pada pembelajaran dengan menggunakan metode demonstrasi alat peraga hanya digunakan oleh guru dan beberapa siswa saja, sehingga siswa tidak terlibat secara langsung dalam mempelajari dan menemukan konsep. Konsep yang mereka dapatkan adalah konsep yang hanya bersumber dari guru saja. Hal tersebut membawa dampak yang kurang positif bagi siswa untuk mendapatkan pengetahuan yang disampaikan oleh guru dan mengurangi kreativitas siswa da-lam proses pembelajaran IPA. Dengan demikian pembelajaran IPA dengan menggunakan metode demonstrasi menyebabkan keterampilan proses IPA siswa menjadi lebih rendah daripada pem-belajaran IPA yang menggunakan metode eksperimen.

Skor rata-rata hasil penilaian setiap aspek keterampilan proses IPA kelompok eksperimen dapat dilihat pada Gambar 1.

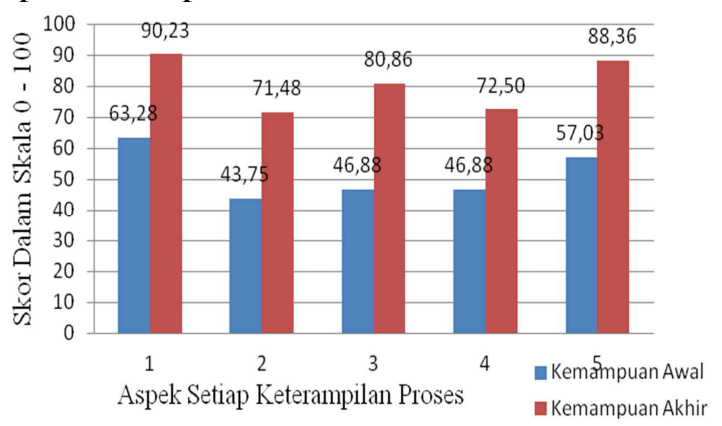

Keterangan: 1) Mengamati ; 2) Memprediksi; 3) Menggolongkan; 4) Menyimpulkan dan 5) Mengkomunikasikan

Gambar 1. Grafik Skor Rata-rata Setiap Aspek Keterampilan Proses IPA Kelompok Eksperimen

Skor rata-rata hasil penilaian setiap aspek keterampilan proses IPA pada kelompok kontrol dapat dilihat pada Gambar 2.

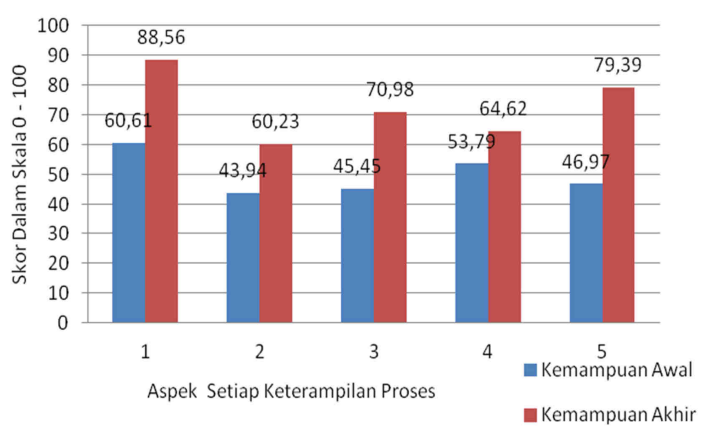

Keterangan: 1) Mengamati ; 2) Memprediksi; 3) Menggolongkan; 4) Menyimpulkan dan 5) Mengkomunikasikan

Gambar 2. Grafik Skor Rata-rata Setiap Aspek

Keterampilan Proses IPA Kelompok Kontrol

Berdasarkan Gambar 1 dan 2 menunjukkan adanya peningkatan untuk keseluruhan aspek keterampilan proses IPA baik pada kelom-pok eksperimen maupun kemompok kontrol. Dari kelima aspek keterampilan proses yang di observasi, urutan aspek keterampilan proses IPA yang diperoleh baik kelompok eksperimen mau-pun kelompok kontrol adalah sama. Urutan aspek keterampilan proses IPA sesuai dengan tingkatan yang paling tinggi ke tingkatan yang paling rendah yaitu (1) keterampilan mengamati, (2) keterampilan mengkomunikasikan, (3) keteram-pilan menggolongkan, (4) keterampilan menyimpulkan dan (5) keterampilan memprediksi.

\section{Keterampilan mengamati}

Pada kelompok eksperimen skor rata-rata kemampuan awal keterampilan mengamati sebesar 63,28 dan skor rata-rata kemampuan akhirnya sebesar 90,23. Pada kelompok kontrol skor rata-rata kemampuan awal keterampilan mengamati sebesar 60,61 dan skor rata-rata kemampuan akhir sebesar 88,56. Keterampilan mengamati adalah kemampuan menggunakan panca indera untuk memperoleh data atau informasi. Menje-laskan bahwa keterampilan mengamati ini menjadi dasar untuk keterampilan proses yang lain. Keterampilan mengamati ini merupakan keterampilan proses yang terpenting, karena kebenaran ilmu yang diperoleh bergantung pada kebenaran dan kecermatan hasil observasi (Dimyati \& Mudjiono, 2009, p.142).

Keterampilan mengamati berada pada posisi tertinggi baik pada kelompok eksperimen maupun kelompok kontrol meskipun skor ratarata kelompok eksperimen (3,60 dengan nilai konversi 90,12) lebih tinggi dibandingkan kelom-pok kontrol (3,54 dengan nilai konversi 
88,61). Hal ini disebabkan siswa yang melakukan ekspe-rimen dapat berinteraksi langsung dalam kelom-pok kecilnya sehingga proses mengamati yang mereka lakukan langsung dialami oleh siswa itu sendiri. Dengan melakukan eksperimen siswa dapat lebih aktif tidak hanya melihat guru atau siswa lain yang melakukan eksperimen. Sedang-kan pada pembelajaran IPA yang menggunakan metode demonstrasi siswa hanya melihat dan mengamati demonstrasi yang dilakukan oleh guru yang dibantu oleh dua orang siswa.

\section{Keterampilan mengkomunikasikan}

Keterampilan mengkomunikasikan mengalami peningkatan. Pada kelompok eksperimen skor rata-rata kemampuan awal keterampilan mengkomunikasikan sebesar 57,03 dan skor rata-rata kemampuan akhirnya sebesar 88,36 . Pada kelompok kontrol skor rata-rata kemampuan awal keterampilan mengkomunikasikan sebesar 46,97 dan skor rata-rata kemampuan akhir sebesar 79,39. Keterampilan mengko-munikasikan merupakan keterampilan proses IPA yang berkaitan dengan pengamatan.

Hasil observasi yang dilakukan di SMP Diponegoro Depok baik pada kelompok eksperimen dan kontrol, keterampilan mengkomunikasikan berada di posisi kedua setelah keterampilan mengamati meskipun skor rata-rata kelompok eksperimen (3,53 dengan nilai konversi $85,26)$ lebih tinggi dibandingkan kelompok kontrol (3,19 dengan nilai konversi 79,72). Hal ini disebabkan pada kelompok eksperimen siswa melakukan kegiatan eksperimen secara mandiri sehingga siswa dapat mendiskripsikan kegiatan yang diamati dan dapat dimengerti oleh siswa. Dengan demikian siswa yang melakukan pengamatan secara langsung dan benar, akan sangat membantu proses dalam melakukan aktivitas mengkomunikasikan.

Pada pembelajaran yang menggunakan metode demonstrasi siswa hanya melihat dan mengamati apa yang didemonstrasikan oleh guru bersama dua orang siswa lainnya bukan mela-kukan sendiri. Siswa dengan hanya melihat dan mengamati saja maka untuk melakukan aktivitas mengkomunikasikan hasilnya lebih rendah di-bandingkan dengan yang melakukan secara langsung.

\section{Keterampilan Menggolongkan}

Keterampilan menggolongkan mengalami peningkatan. Pada kelompok eksperimen skor rata-rata kemampuan awal keterampilan meng- golongkan sebesar 46,88 dan skor rata-rata kemampuan akhirnya sebesar 80,86. Pada kelom-pok kontrol skor rata-rata kemampuan awal keterampilan menggolongkan sebesar 45,45 dan skor rata-rata kemampuan akhir sebesar 70,98.. Keterampilan menggolongkan merupakan kete-rampilan untuk menggolongkan objek penga-matan yaitu cahaya, atas dasar perbedaan dan persamaan sifat yang dimiliki. Suatu hasil pengamatan yang cermat dan benar sangat mem-bantu proses menggolongkan, karena di dalam-nya terkandung unsur-unsur persamaan dan per-bedaan.

Hasil observasi yang dilakukan di SMP Diponegoro Depok baik pada kelompok eksperimen dan kelompok kontrol, keterampilan menggolongkan berada di posisi ketiga setelah keterampilan mengamati dan keterampilan mengkomunikasikan meskipun skor rata-rata kelompok eksperimen (3,23 dengan nilai konversi 80,67$)$ lebih tinggi dibandingkan kelompok kontrol (2,84 dengan nilai konversi 71,07).

Pada pembelajaran dengan metode eksperimen siswa melaksanakan sendiri kegiatan eksperimen sehingga rata-rata siswa dapat meng-golongkan peristiwa yang diamati berdasarkan hasil pengamatan dengan benar. Dengan demi-kian siswa mampu membedakan dan mencari persamaan suatu peristiwa yang terjadi dalam kehidupan sehari-hari yang berkaitan dengan cahaya serta hubungan satu dengan yang lainnya. Pembelajaran IPA dengan metode demonstrasi siswa tidak melaksanakan sendiri kegiatan eksperimen namun hanya melihat dan mengamati demonstrasi oleh guru dan dua orang siswa, sehingga rata-rata siswa dalam keterampilan menggolongkan lebih rendah dibandingkan siswa yang melaksanakan sendiri kegiatan eksperimen.

\section{Keterampilan Menyimpulkan}

Keterampilan menyimpulkan mengalami peningkatan. Pada kelompok eksperimen skor rata-rata kemampuan awal keterampilan menyimpulkan sebesar 46,88 dan skor rata-rata kemampuan akhirnya sebesar 72,50. Pada kelom-pok kontrol skor rata-rata kemampuan awal kete-rampilan menyimpulkan sebesar 53,79 dan skor rata-rata kemampuan akhir sebesar 64,62. Data tersebut menunjukkan skor rata-rata kelompok eksperimen lebih tinggi dibandingkan kelompok kontrol. Keterampilan menyimpulkan merupakan keterampilan untuk memberikan suatu tafsiran yang dibuat berdasarkan fakta hasil pengamatan. 
Pada kelompok eksperimen dan kelompok kontrol keterampilan menyimpulkan posisinya berada setelah keterampilan mengamati, mengkomunikasikan dan menggolongkan meskipun skor rata-rata kelompok eksperimen $(2,89$ dengan nilai konversi 72,26) lebih tinggi dibandingkan kelompok kontrol (2,59 dengan nilai konversi 63,84). Hal ini disebabkan pembelajaran dengan metode eksperimen dengan melakukan ekspe-rimen sendiri siswa dapat membuat kesimpulan sesuai hasil pengamatan yang dilakukan. Pem-belajaran dengan metode demonstrasi siswa hanya melihat dan mengamati demonstrasi dari guru sehingga dalam membuat kesimpulan ada yang menuliskannya tidak lengkap. Pada kenyataannya tidak semua siswa menuliskan kesimpulan secara lengkap sesuai dengan perintah yang terdapat pada LKS.

\section{Keterampilan Memprediksi}

Keterampilan memprediksi mengalami peningkatan. Pada kelompok eksperimen skor rata-rata kemampuan awal keterampilan memprediksi sebesar 43,75 dan skor rata-rata kemam-puan akhirnya sebesar 71,48. Pada kelompok kontrol skor rata-rata kemampuan awal keteram-pilan memprediksi sebesar 43,94 dan skor rata-rata kemampuan akhir sebesar 60,23 . Data tersebut menunjukkan skor rata-rata kelompok eksperimen lebih tinggi dibandingkan kelompok kontrol. Keterampilan memprediksi merupakan perbuatan membuat prediksi tentang materi yang berkaitan dengan cahaya yang terjadi setelah percobaan atau demonstrasi dilakukan..

Pada kelompok eksperimen dan kelompok kontrol keterampilan memprediksi posisinya berada pada tingkatan terendah setelah keterampilan mengamati, mengkomunikasikan, menggolongkan, dan menyimpulkan meskipun skor rata-rata kelompok eksperimen (2,86 dengan nilai konversi 71,47) lebih tinggi dibandingkan kelom-pok kontrol (2,40 dengan nilai konversi 60,04). Hal ini disebabkan pada kelompok eksperimen alat dan bahan yang digunakan telah tersedia pada kelompok masing-masing sehingga mem-bantu siswa dalam membuat prediksi.

Pada kelompok eksperimen siswa yang alat dan bahannya sudah tersedia di masingmasing kelompok dapat menyusun alat seperti menyusun karton secara sejajar meskipun lampu senter belum dinyalakan untuk membuat prediksi tentang sifat perambatan cahaya, melihat ba-yangan wajah yang dibentuk oleh cermin cekung dan cermin cembung dengan cara mendekatkan dan menjauhkan cermin dari depan wajah. Pada kelompok kontrol alat dan bahan tidak tersedia di meja setiap kelompok namun hanya ada di meja guru, sehingga siswa tidak dapat menyusun alat seperti pada kelompok eksperimen untuk mem-permudah membuat prediksi.

\section{Hasil Belajar IPA Siswa Selama Pembelajaran}

Berdasarkan deskripsi data pretest dan posttest hasil belajar IPA baik pada kelompok eksperimen maupun kelompok kontrol meningkat. Peningkatan ini dapat dilihat dari skor ratarata pretest dan posttest hasil belajar IPA. Pada kelompok eksperimen skor rata-rata pretest hasil belajar IPA sebesar 39,34 dan skor rata-rata posttest sebesar 80,44 . Peningkatan pada kelompok kontrol skor rata-rata pretest hasil belajar IPA sebesar 39,91 dan skor rata-rata posttest sebesar 72,21. Selain itu peningkatan hasil belajar IPA kelompok eksperimen dapat dilihat dari persentase siswa yang telah mencapai ketuntasan belajar minimal sebesar 96,9\% sedangkan pada kelompok kontrol persentase siswa yang telah mencapai ketuntasan belajar minimal yaitu sebesar 84,8\% dengan KKM yang ditetapkan oleh sekolah sebesar 65. Hal ini menunjukkan bahwa pembelajaran IPA baik dengan metode eksperimen maupun metode demonstrasi efektif untuk meningkatkan hasil belajar IPA karena telah melebihi dari $75 \%$ siswa yang mencapai KKM. Data tersebut menun-jukkan peningkatan persentase ketuntasan belajar kelompok eksperimen lebih tinggi dibandingkan kelompok kontrol.

Hasil uji univariat dengan uji independent sample t test dengan nilai signifikansi yaitu (Sig2-tailed) sebesar 0,020 (Sig-2tailed) < 0,025). Hal ini berarti bahwa hasil belajar IPA siswa yang pembelajarannya menggunakan metode eksperimen lebih tinggi dari hasil belajar IPA siswa yang pembelajarannya menggunakan metode demonstrasi. Dengan demikian, pembelajaran IPA yang menggunakan metode eksperimen lebih efektif dan signifikan dalam mening-katkan hasil belajar IPA siswa dibandingkan pembelajaran IPA dengan metode demonstrasi.

Pembelajaran dengan metode eksperimen siswa dapat melakukan pengamatan secara langsung yang berkaitan dengan eksperimen tentang cahaya pada kelompok kecil. Dalam pembe- 
lajaran menggunakan metode eksperimen, proses pembelajaran IPA menuntut keterlibatan siswa secara aktif, sehingga keterampilan proses siswa lebih dapat berkembang. Metode eksperimen dalam pembelajaran IPA memiliki keuntungan antara lain: siswa lebih kreatif melakukan kegiatan, memberi kesempatan menggunakan seluruh panca indra, siswa dapat melakukan kegiatan sesuai metode ilmiah dan dapat mene-mukan sendiri pengetahuan (hukum, konsep dan prinsip yang berkaitan dengan materi cahaya). Kemampuan intelektual yang dapat dilatih oleh siswa merupakan kemampuan yang dibutuhkan untuk melakukan berbagai aktivitas, berpikir dan dapat memecahkan masalah, sehingga hasil belajar yang diperoleh akan meningkat. Dengan demikian proses pembelajaran IPA dengan menggunakan metode eksperimen dapat mening-katkan keterampilan proses dan juga mening-katkan hasil belajar IPA siswa.

Dengan melakukan demonstrasi perhatian siswa dapat dipusatkan kepada hal yang dianggap penting oleh guru sehingga hal yang penting dapat diamati secara teliti. Pembelajaran dengan metode demonstrasi menarik karena siswa tidak hanya mendengar, tetapi melihat peristiwa yang terjadi meskipun hanya dengan demonstrasi.

Pada kelompok kontrol, siswa hanya melihat dan mengamati demonstrasi yang dilakukan oleh guru dan dua siswa lainnya sehingga untuk berdiskusi kelompok hanya sebatas yang diamati oleh siswa, membuat laporan yang kurang lengkap serta dalam menjelaskan kembali hasil pengamatannya ini terbatas dengan yang diamati siswa. Dengan demikian hasil belajar IPA yang diperoleh pada kelompok eksperimen lebih tinggi dibandingkan dengan hasil belajar IPA pada kelompok kontrol.

Berdasarkan uraian tersebut, pembelajaran IPA menggunakan metode eksperimen lebih efektif dalam meningkatkan keterampilan proses dan hasil belajar IPA dibandingkan dengan pembelajaran IPA menggunakan metode demon-strasi siswa kelas VIII SMP Diponegoro Depok Sleman.

\section{SIMPULAN}

Berdasarkan hasil analisis data dan pembahasan maka dapat disimpulkan sebagai berikut: 1) pembelajaran IPA menggunakan metode eksperimen efektif ditinjau dari keterampilan proses dan hasil belajar IPA siswa kelas VIII SMP Diponegoro Depok Sleman, 2) pembe-lajaran IPA menggunakan metode eksperimen lebih efektif dalam meningkatkan keterampilan proses dan hasil belajar IPA dibandingkan dengan pembelajaran IPA menggunakan metode demonstrasi.

Pelaksanaan metode eksperimen dalam pembelajaran IPA lebih efektif dari metode demonstrasi terhadap keterampilan proses dan hasil belajar IPA siswa SMP. Oleh karena itu, disarankan kepada para guru untuk dapat menerapkan pembelajaran IPA dengan metode eksperimen sehingga dapat meningkatkan keterampilan proses dan hasil belajar IPA khususnya pada materi cahaya. Selain itu materi yang digunakan perlu diperluas lagi sehingga memungkinkan generalisasi yang lebih luas.

\section{DAFTAR PUSTAKA}

Abrahams, I., \& Millar, R. (2008). Does practical work really work? A study of the effectiveness of practical work as a teaching and learning method in school science. International Journal of science Education, 30 (14), 1945 - 1969.

Alia, N., \& Supriyono. (2013). Penerapan model direct instruction dengan menggunakan keterampilan proses sains untuk meningkatkan hasil belajar siswa kelas X SMA Negeri 1 Bangkalan pada materi pokok azas black. Jurnal Inovasi Pendidikan Fisika, 2 (3), 50 - 54. Retrive from http://ejournal.unesa.ac.id/index.php/inov asipendidikanfisika/article/download/355 $1 / 1931$.

Ango, M. L. (2002). Mastery of science process skills and their effective use in the teaching of science: An educology of science educa-tion in the Nigeria context. International Journal of Educology, 1 (1).

Arikunto, S. (2001). Dasar-dasar evaluasi pendidikan (Edisi Revisi, Cetakan ke-2). Jakarta: Bumi Aksara

Azwar, S. (2013). Penyusunan skala Psikologi (Edisi 2. Cetakan IV). Yogyakarta: Pustaka Pelajar.

Chiappetta, E. L., \& Collette, A. T. (1994). science instruction in the middle and secondary school ( $7^{\text {th }} E d$.). New York: Maxcmillan Publishing Company.

Depdiknas. (2006a). Peraturan Menteri Pendidikan Nasional Republik Indonesia Nomor 22 Tahun 2006 tentang Standar Isi 
untuk Satuan Pendidikan Dasar dan Menengah.

Depdiknas. (2006b). Peraturan Menteri Pendidikan Nasional Republik Indonesia Nomor 23 Tahun 2006 tentang Standar Kompe-tensi Lulusan untuk Satuan Pendidikan Dasar dan Menengah

Djamarah, S. B., \& Zain, A. (1996). Strategi belajar mengajar. Jakarta: Rineka Cipta.

Listyaningrum, R. I., Sajidan, S., \& Suciati, S. (2012). Penerapan model pembelajaran inductive thinking berbasis keterampilan proses sains untuk meningkatkan kualitas pembelajaran biologi siswa kelas X.7 SMA Negeri 2 Karanganyar Tahun Pelajaran 2011/2012. Jurnal Pendidikan Biologi, 4 (1).

Majid, A. (2013). Strategi pembelajaran. Bandung: PT Remaja Rosdakarya.

Murwani, S., \& Wibowo, Y. (2013). Pengaruh pendekatan contextual teaching and learning dengan metode eksperimen lapangan dan eksperimen laboratorium terhadap prestasi belajar siswa kelas $\mathrm{X}$ SMAN 2 Yogyakarta. Jurnal Pendidikan Matematika dan Sains, 1 (2), 134 - 139.

Nopitasari, A., Indrowati, M., \& Santosa, S. (2012). Pengaruh metode student created case studies disertai media gambar terhadap keterampilan proses sains siswa kelas X SMA Negeri 1 Mojolaban Sukoharjo. Jurnal Pendidikan Biologi, 4 (3).

Priyatno, D. (2012). Belajar praktis analisis parametrik dan non parametrik dengan SPSS. Yogyakarta: Gava Media

Purnawirawanti, Y., Sarwanto, S., \& Sugiyarto, S. (2013). Pendekatan kontekstual melalui metode demonstrasi dan simulasi dalam pembelajaran IPA ditinjau dari kecerdasan spasial dan interaksi sosial siswa. Jurnal Inkuiri, 2 (1), 76 - 87.
Roestiyah, N. K. (2008). Strategi belajar mengajar. Jakarta: Rineka Cipta

Sagala, S. (2003). Konsep dan makna pembelajaran. Bandung: Alfabeta.

Subamia, I. M. P. (2012). keterampilan proses ipa dan hasil belajar siswa pada pembelajaran menggunakan pendekatan starter experi-ment. Jurnal Pendidikan dan Pengajaran, 45 (1).

Subekti, Y., \& Ariswan, A. (2016). Pembelajaran fisika dengan metode eksperimen untuk meningkatkan hasil belajar kognitif dan keterampilan proses sains. Jurnal Inovasi Pendidikan IPA, 2 (2), 252-261. doi:http://dx.doi.org/10.21831/jipi.v2i2.62 78

Sugiyono, S. (2011). Metodologi penelitian pendidikan (pendekatan kuantitatif, kualitatif dan R\&D). Bandung: CV. Alfabeta

Trihendradi, C. (2013). Step by step IBM SPSS 21: Analisis data statistik. Yogyakarta: Andi Offset

Zuldafrial. (2012). Strategi belajar mengajar. Surakarta: Cakrawala Media.

\section{PROFIL SINGKAT}

\section{Anik Purwanti.}

Lahir di Sleman, 21 Desember 1981. Lulusan S-1 FMIPA Jurusan Pendidikan Fisika di Universitas Sarjanawiyata Tamansiswa pada bulan Mei 2003. Telah mengajar di SMP N 2 Pangkalpinang sejak tahun 2005. Selanjutnya pada tahun2012 beliau menempuh S2 di Program Studi Pendidikan sain.

\section{Dr. P. Yatiman, M.Sc}

Beliau dilahirkan di Sleman, pada tanggal 09 Mei 1951. Beliau adalah salah satu dosen FMIPA khususnya Jurusan Pendidikan Kimia di Universitas Negeri Yogyakarta. 